\title{
Childhood Uveitis
}

\section{Uveitis im Kindesalter}

Author

Stephan Thurau

\author{
Affiliation \\ Augenklinik, Klinikum der LMU München, München, \\ Deutschland
}

Key words

uveitis, paediatric ophthalmology, therapy

Schlüsselwörter

Uveitis, Kinderophthalmologie, Therapie

$\begin{array}{ll}\text { received } & 18.8 .2020 \\ \text { accepted } & 17.9 .2020\end{array}$

Bibliography

Klin Monatsbl Augenheilkd 2020; 237: 1177-1186

DOI 10.1055/a-1252-5281

ISSN 0023-2165

(C) 2020. Thieme. All rights reserved.

Georg Thieme Verlag KG, Rüdigerstraße 14, 70469 Stuttgart, Germany

\section{Correspondence}

Prof. Stephan Thurau

Augenklinik, Klinikum der LMU München

Mathildenstraße 8, 80336 München, Deutschland

Phone: $+49(0) 89440053811$, Fax: + 49(0) 89440053045

stephan.thurau@med.uni-muenchen.de

\begin{abstract}
Childhood uveitis is an ophthalmological challenge, since on the one hand it often remains asymptomatic and difficult to detect, and on the other hand it often has a chronic course and is associated with a high risk of complications threatening the vision. The most important risk factors for childhood uveitis are underlying rheumatic diseases; recommendations for ophthalmological monitoring have been developed together with paediatric rheumatologists. Intermediate and posterior uveitis are rare in children. The therapy must effectively control inflammation and at the same time cause only minimal side effects. Since steroids in particular cause side effects frequently, an immunosuppressive therapy must be initiated early in an interdisciplinary cooperation with paediatric rheumatologists and parents with the goal of minimising steroids.
\end{abstract}

\section{ZUSAMMENFASSUNG}

Die Uveitis im Kindesalter ist eine ophthalmologische Herausforderung, da sie einerseits häufig symptomlos bleibt und schwer zu erkennen ist und andererseits vielfach chronisch verläuft sowie mit einem hohen Risiko für visusbedrohende Komplikationen behaftet ist. Die wichtigsten Risikofaktoren für eine Uveitis im Kindesalter sind rheumatische Grunderkrankungen; gemeinsam mit den Kinderrheumatologen wurden Empfehlungen für die ophthalmologische Überwachung erarbeitet. Intermediäre und posteriore Uveitiden sind bei Kindern selten. Die Therapie muss Entzündung effektiv kontrollieren können, darf aber gleichzeitig nur ein Minimum an Nebenwirkungen verursachen. Da gerade die Steroide häufig Nebenwirkungen verursachen, muss frühzeitig in interdisziplinäre Zusammenarbeit mit Kinderrheumatologen und Eltern eine immunsuppressive Therapie mit dem Ziel der Steroidminimierung eingeleitet werden.

\section{Introduction}

With an estimated prevalence of $3 / 100,000$, uveitis in children is rarer than in adults [1]. Although uveitis is often symptomless in childhood, it can still lead to considerable visual impairments and chronic damage. As such, the early recognition and treatment of the disease is decisive for long-term visual outcome.

Uveitis in children and adolescents can be associated with rheumatic or rare neurological diseases. Differential diagnosis must also consider infectious causes and in childhood rarely also tumours (masquerade syndrome). As in adults, uveitis in children is also classified according to SUN (standardisation of uveitis nomenclature) criteria [2]. For classification based on anatomical localisation, only direct inflammation signs such as cells and the Tyndall effect in the anterior chamber and vitreous body as well as retinal or vasculitic infiltrates are taken into account. Although complications of inflammatory reactions such as synechiae, media opacity and macular oedema often present a particular therapeu- 


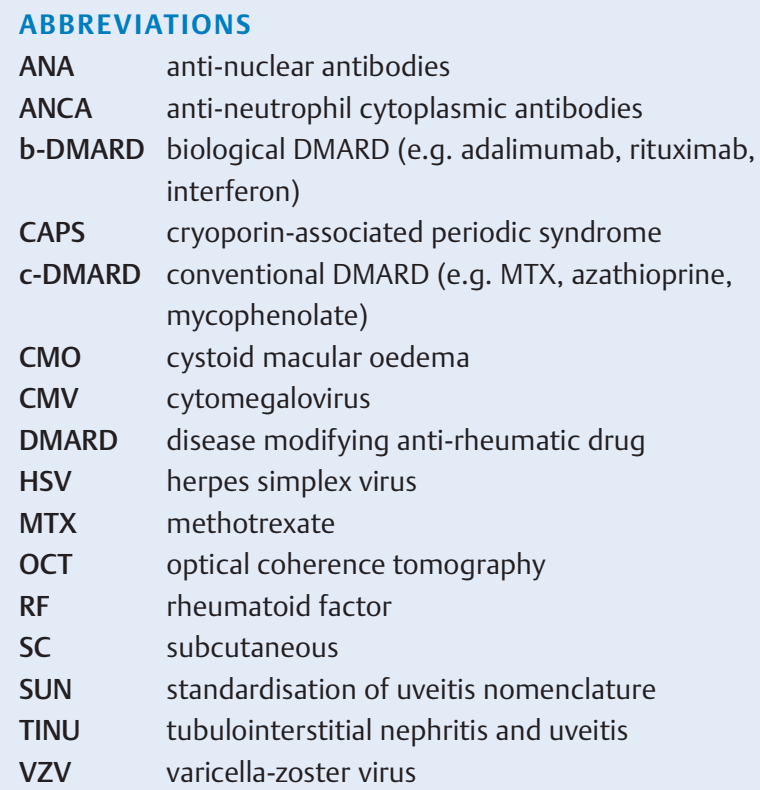

tic challenge, they are not taken into account for the locationbased classification of uveitis. The correct localisation of the centre of inflammation is, however, of critical importance for subsequent diagnosis and treatment.

Since 2011, the Association of the Scientific Medical Societies in Germany (AWMF) has provided a consensus-based guideline on the diagnosis and anti-inflammatory treatment of uveitis associated with juvenile idiopathic arthritis which was created and updated (2018) under the direction of Arnd Heiligenhaus, Münster $[3,4]$.

In this article, childhood uveitis is classified based on the anatomical localisation of the centre of inflammation. The data on the percentual distribution varies heavily. The frequency of anterior uveitis is given as $39-78 \%$, intermediate uveitis as up to $33 \%$, posterior uveitis as $4-59 \%$ and panuveitis as $1-31 \%$ [5].

\section{Anterior Uveitis}

The most significant association of an underlying disease to anterior uveitis is that with juvenile idiopathic arthritis, classified according to the International League of Associations for Rheumatology, with the subtypes rheumatoid factor (RF)-negative polyarthritis, Rf-positive polyarthritis, systemic polyarthritis, oligoarthritis, psoriatic arthritis and enthesitis-associated arthritis [\{6]. Other important rheumatic associations include those with juvenile ankylosing arthritis and reactive arthritis. This relationship with juvenile idiopathic arthritis (JIA) and other rheumatic diseases is presented systematically in $>$ Table 1.

\section{Asymptomatic and symptomatic anterior uveitis}

Many types of uveitis that are associated with systemic diseases are chronic and asymptomatic, which means that the uveitis causes little or no pain and the eyes usually aren't even red. This is a particularly common problem with oligoarthritis and RF-neg- ative polyarthritis ( $\triangleright$ Table 2 ). RF-positive polyarthritis and systemic arthritis (Still's disease), on the other hand, are associated with uveitis very rarely or not at all. If uveitis were to be found in a child with Still's disease, the diagnosis of Still's disease would even have to be thrown in doubt.

Subjectively noticeable symptoms occur more frequently in diseases associated with HLA-B27; these primarily include enthesitis-associated arthritis, juvenile ankylosing arthritis, reactive arthritis and inflammatory bowel disease. Symptomatic uveitis can also occur with systemic vasculitis, Behçet's disease, cryoporin-associated periodic syndrome and TINU syndrome as well as with infections ( $\vee$ Table 2 ).

\section{Inflammation type: granulomatous or non-granulomatous}

Similar to in adults, differentiation must be made between granulomatous and non-granulomatous types of inflammation ( $\vee$ Table 2). Granulomas in the form of mutton-fat endothelial deposits, Koeppe nodules and Busacca nodules are often found in sarcoidosis-associated uveitis and Blau syndrome, although they also occur in chronic intraocular infections with the viruses of the herpes family (HSV, VZV, CMV, EBV) and toxoplasma gondii. In contrast to this, the types of uveitis associated with HLA-B27 or HLA-B51 (Behçet's disease) are typically non-granulomatous. Most common here are fibrin and individual, usually small cells in the anterior chamber and on the corneal endothelium. The types of uveitis associated with ANA are usually non-granulomatous, but granulomatous inflammation has also been observed.

\section{Screening exams in children with juvenile idiopathic arthritis}

Due to the lack of subjective symptoms, it is important to check children with JIA regularly due to their increased risk of uveitis. In such cases the likelihood of developing uveitis and the risk of it becoming severe depend on the subtype of JIA, the ANA status, the age of onset and disease duration. All these factors have lead to very differentiated recommendations, which are compiled in - Table 3 [3]. They allows us to reliably identify a case of uveitis in its early stages without having to put the child through unnecessary examinations. Following a thorough initial examination with a funduscopy and cycloplegic refraction, later check-ups in accordance with the table require only examination with a slit lamp in order to uncover a case of uveitis. If a case of uveitis is newly diagnosed, the ocular fundus must be thoroughly examines with special attention to the complications papillitis and cystoid macular oedema. OCT is very helpful on this regard [7].

\section{Intermediate Uveitis}

Intermediate uveitis with its centre of inflammation in the vitreous body and peripheral retina anterior to the equator usually occurs as pars planitis as a disease in its own right and much more rarely in the scope of sarcoidosis (including Blau syndrome) or juvenile multiple sclerosis [8]. Even though both aforementioned underlying diseases combined occur in less than $10 \%$ of cases of juvenile intermediate uveitis, appropriate paediatric/neurological examinations should nonetheless be performed. In contrast, 
- Table 1 Uveitis localisation and common underlying diseases/associations.

\begin{tabular}{|c|c|}
\hline Localisation & Association/underlying disease \\
\hline Anterior uveitis & $\begin{array}{l}\text { - Juvenile idiopathic arthritis with the subtypes: } \\
\text { - RF-negative polyarthritis } \\
\text { - RF-positive polyarthritis (very rare) } \\
\text { - Systemic polyarthritis } \\
\text { - Oligoarthritis } \\
\text { - Psoriatic arthritis } \\
\text { - Enthesitis-associated arthritis } \\
\text { - Juvenile ankylosing arthritis } \\
\text { - Reactive arthritis } \\
\text { - Lyme arthritis } \\
\text { - Inflammatory bowel disease } \\
\text { - Cryoporin-associated periodic syndrome (CAPS) with the subtypes } \\
\text { - Neonatal onset multisystem inflammatory disease (CINCA/NOMID) } \\
\text { - Muckle-Wells syndrome (MWS) } \\
\text { - Familial cold autoinflammatory syndrome (FCAS) } \\
\text { - tubulointerstitial nephritis and uveitis (TINU) } \\
\text { - Infections: Herpes simplex virus (HSV), varicella-zoster virus (VZV), cytomegalovirus (CMV), toxoplasmosis }\end{array}$ \\
\hline Intermediate uveitis & $\begin{array}{l}\text { - Demyelinating diseases (e.g. MS) } \\
\text { - Tubulointerstitial nephritis and uveitis (TINU) }\end{array}$ \\
\hline Posterior uveitis and panuveitis & $\begin{array}{l}\text { - Sarcoidosis, Blau syndrome } \\
\text { - Behçet's disease } \\
\text { - Systemic vasculitis, collagenosis (e.g. Kawasaki syndrome) } \\
\text { - Lyme arthritis } \\
\text { - Infections: Herpes simplex virus (HSV), varicella-zoster virus (VZV), cytomegalovirus (CMV), toxoplasmosis }\end{array}$ \\
\hline
\end{tabular}

- Table 2 Asymptomatic and potentially symptomatic anterior uveitis.

\begin{tabular}{|c|c|c|}
\hline Characteristic & Underlying disease & Note \\
\hline \multirow[t]{4}{*}{ Mostly asymptomatic } & $\begin{array}{l}\text { - RF-negative polyarthritis } \\
\text { - RF-positive polyarthritis } \\
\text { - Systemic polyarthritis } \\
\text { - Oligoarthritis } \\
\text { - Psoriatic arthritis }\end{array}$ & $\begin{array}{l}\text { - Often ANA-positive } \\
\text { - Usually non-granulomatous }\end{array}$ \\
\hline & Sarcoidosis/Blau syndrome & Granulomatous \\
\hline & TINU & Different inflammation types \\
\hline & Toxoplasmosis & $\begin{array}{l}\text { Anterior involvement in focal necrotising chorioretinitis, } \\
\text { usually granulamatous }\end{array}$ \\
\hline \multirow[t]{6}{*}{ Potentially symptomatic } & $\begin{array}{l}\text { - Oligoarthritis (in older children) } \\
\text { - Lyme arthritis } \\
\text { - Inflammatory bowel disease }\end{array}$ & Usually non-granulomatous \\
\hline & $\begin{array}{l}\text { - Psoriatic arthritis (at school age) } \\
\text { - Enthesitis-associated arthritis } \\
\text { - Juvenile ankylosing arthritis } \\
\text { - Reactive arthritis }\end{array}$ & Associations with HLA-B27, usually non-granulomatous \\
\hline & Behçet's disease & Association with HLA-B51, non-granulomatous \\
\hline & Systemic vasculitis & ANCA, ANA \\
\hline & CAPS & \\
\hline & Infectious anterior uveitis with HSV, VZV, CMV & Usually granulomatous \\
\hline
\end{tabular}

checking for rheumatism based on the lack of a corresponding association with JIA does not make sense. The most common complications which are each found in 25-35\% of eyes are CMO, cataract, epiretinal membranes and posterior synechiae. Band keratopathy and glaucoma which often occur in anterior uveitis are considerably less common in intermediate uveitis. Treatment of intermediate uveitis should only commence in the case of a reduction in vision associated with an increased risk of developing amblyopia, and certainly if complications occur that can leave structural damage such as CMO, cataract, glaucoma or band keratopathy. 
- Table 3 Uveitis screening with a split lamp in patients with juvenile idiopathic arthritis, provided no uveitis occurred before.

\begin{tabular}{|c|c|c|c|c|}
\hline JIA subgroup & ANA & $\begin{array}{l}\text { Age of onset } \\
\text { (years) }\end{array}$ & $\begin{array}{l}\text { Disease duration } \\
\text { (years) }\end{array}$ & $\begin{array}{l}\text { Recommended frequency of split lamp } \\
\text { examinations (months) in children } \\
\text { without previously diagnosed uveitis. }\end{array}$ \\
\hline \multirow{8}{*}{$\begin{array}{l}\text { - Oligoarthritis } \\
\text { - RF-negative polyarthritis } \\
\text { - psoriatic arthritis } \\
\text { - unclassified arthritis }\end{array}$} & + & $\leq 6$ & $\leq 4$ & $3^{\#}$ \\
\hline & + & $\leq 6$ & $>4$ & 6 \\
\hline & + & $\leq 6$ & $\geq 7$ & 12 \\
\hline & + & $>6$ & $\leq 2$ & 6 \\
\hline & + & $>6$ & $>2$ & 12 \\
\hline & - & $\leq 6$ & $\leq 4$ & 6 \\
\hline & - & $\leq 6$ & $>4$ & 12 \\
\hline & - & $>6$ & n. r. & 12 \\
\hline Enthesitis-associated arthritis & n. r. & n.r. & n. r. & 12 \\
\hline $\begin{array}{l}\text { RF-positive polyarthritis, } \\
\text { systemic polyarthritis }\end{array}$ & n.r. & n. r. & n.r. & 12 \\
\hline $\begin{array}{l}\text { Patients with previously } \\
\text { diagnosed uveitis }\end{array}$ & n.r. & n. r. & n. r. & $\begin{array}{l}\text { According to the progression of the uveitis } \\
\text { on a case-by-case basis }\end{array}$ \\
\hline
\end{tabular}

\section{Posterior Uveitis and Panuveitis}

Posterior uveitis and pan uveitis are considerably less common than anterior uveitis. They are associated with underlying rheumatic diseases such as Behçet's disease and systemic vasculitis, or sarcoidosis in children including the autosomal-dominant inheritable Blau syndrome, while it is frequently the case that no underlying condition can be identified [9].

$5-25 \%$ of Behçet's diagnoses occur in children below the age of 16 , predominantly of Mediterranean descent [10]. The clinical picture covers the classic findings of the disease in adults with hyponon iritis, vitritis, sometimes occlusive retinal vasculitis, focal retinitis, papillitis and $\mathrm{CMO}$. Adalimumab is primarily used in the treatment of these children, but interferons are also used $[11,12]$.

Sarcoidosis in children is rare and can affect all parts of the eye. It occurs mostly occurs on both sides and must not necessarily appear as granulomatous inflammation in all cases [13]. In terms of treatment, the focus is on systemic steroids in $64 \%$ of children; steroid-sparing drugs (MTX, ciclosporin, TNF inhibitors and mycophenolate) are used in $42 \%$ [8].

Toxoplasmosis-chorioretinitis is also seen as a rare cause of uveitis [14]. However, one must assume that there are a relatively large number of unreported cases, because it is asymptomatic as long as it remains limited to the posterior eye segment and, as opposed to rheumatism-associated uveitis, does not present any general signs of disease that might justify a screening. In the case of active inflammation threatening the structures of the posterior pole, it is treated as in adults with antibiotics (preferably trimethoprim/sulphamethoxazole or clindamycin) combined with steroids to inhibit the accompanying inflammatory complications. If previous episodes have already left atrophy in or close to the macula, antibiotic prophylaxis should be carried out with considerably lower doses of trimethoprim/sulphamethoxazole or clindamycin.

\section{Masquerade Syndrome}

Malign diseases in childhood are rare. However, a case of uveitis might be hiding various tumours. Retinoblastoma is the only primary intraocular tumour that occurs in childhood, with very rare first-time diagnoses taking place in the 2nd decade of children's lives. If it is first diagnosed in the scope of intraocular metastasis to the anterior chamber, it can be confused with a case of granulomatous iritis.

In childhood, leukaemia rarely spreads to the eye. This results in bleeding, retinal infiltrates or also choroidal involvement (leopard spots) [15].

\section{Treatment of Uveitis in Children}

\section{Treatment of JIA-associated anterior uveitis (in accordance with AWMF guideline 045/012)}

The treatment of anterior uveitis always begins with highly dosed topical steroids (administered every hour or 30 minutes), which must be reduced to 1-2 times a day depending on inflammation activity ( $\triangleright$ Fig. 1 ) [3].

To reduce the risk of band keratopathy, phosphate-free eyes drops should be used. In Germany (as of August 2020), all prednisolone drops are phosphate free; the active ingredient dexamethasone is only available as Dexapos COMOD in a phosphatefree formulation.

Especially in the case of serious complications such as hypotension, severe Tyndall effect, severe anterior chamber inflammation, dense vitreous opacities or $\mathrm{CMO}$, oral steroids can also be additionally indicated with an initial dose of $1-1.5 \mathrm{mg}$ per $\mathrm{kg}$ bodyweight ( $\bullet$ Fig. 2). If it is not possible to reduce the drop administration frequency to 1-2 times a day and discontinue the 
Antientzündliche Therapie der Uveitis bei juveniler idiopathischer Arthritis

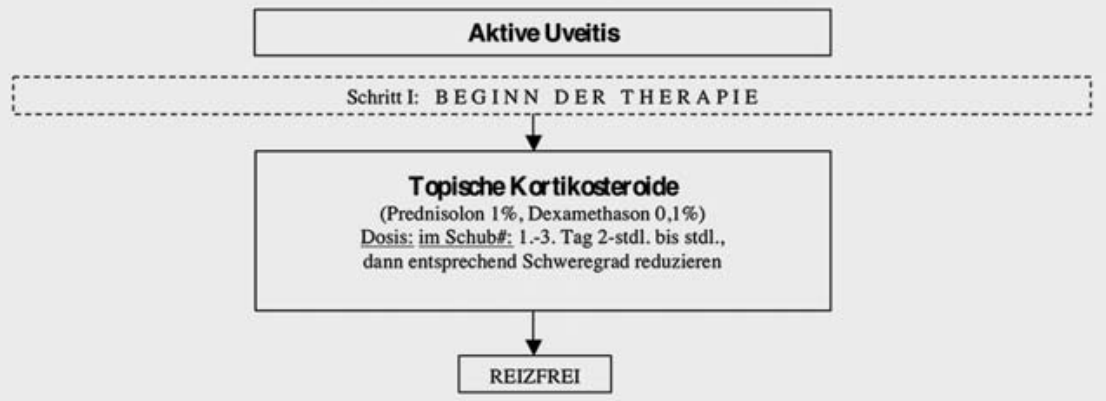

- Fig. 1 Step I of anti-inflammatory treatment of uveitis associated with juvenile idiopathic arthritis in accordance with the AWMF guideline 045012. JIA-associated uveitis is an anterior uveitis. As a result, the first step is topical treatment. It initially commences with the high-potency steroids prednisolone or dexamethasone and should be administered every 30-60 minutes for the first 1-3 days. Over the course of treatment, the drops can be reduced slowly depending on the severity of the uveitis and stopped when inflammation disappears. Eye ointments aggravate the virus and must only be used very sparingly on children due to the risk of amblyopia (e.g. only at night). If prognostically unfavourable factors for chronic sight reduction already exist at the time of diagnosis, systemic corticosteroids are already indicated from the start (see > Fig. 2). Source: Heiligenhaus A, Minden K, Tappeiner C et al. Leitlinie 045-012, S2k, Diagnostik und antientzündliche Therapie der Uveitis bei juveniler idiopathischer Arthritis. 2018. Im Internet (Stand: 06.09.2020): https://www.awmf.org/leitlinien/detail/II/045-012.html [rerif]

oral steroids within 3 months, the risk of drug-induced side effects, including stunted growth, increases, and a systemic DMARD (disease-modifying anti-rheumatic drug) treatment must be commenced. Differentiation is made between c-DMARDs (conventional) and b-DMARDs (biological).

The DMARD of choice remains methotrexate (MTX), a cDMARD. Adalimumab (TNF inhibitor) and other biologics (bDMARDs) are only used as a second choice. Detailed information on the treatment steps is presented in - Figs. 1-3, which are taken from the AWMF guideline 045/012 [3]. Only in rare cases must other biologics be used off-label as a 4th treatment step. This article forgoes a more detailed presentation of the steps and refers instead to the aforementioned guideline $045 / 012$ for more information.

Before starting a DMARD treatment, an examination by a paediatric rheumatologist or experienced paediatrician is required to reduce the risks and side effects of treatment. Due to the increased risk of infection during an immunosuppressive DMARD therapy, it is advisable to complete all required vaccinations recommended by the standing vaccination committee (StIKo) if possible before treatment starts. However, this is often not possible in the case of severe uveitis, because the grace period for immunosuppression following a vaccination cannot be maintained due to the urgency of the threat to the child's vision. In general it is the case that live vaccines are contraindicated under immunosuppressive therapy, while killed vaccines can be administered safely; however, a sufficient level of vaccination can sometimes not be achieved during immunosuppressive therapy. In such cases, the risks must be weighed up together with the child's parents and paediatrician or paediatric rheumatologist.

Methotrexate is administered once per week. The dose is usually 10 to $15 \mathrm{mg} / \mathrm{m}^{2}$ body surface area. MTX can be administered orally or subcutaneously; tolerance is often better with SC administration. As absorption from the gastrointestinal tract is not al- ways reliable and complete, SC administration is preferable in this aspect as well. Close cooperation with the child's paediatrician or paediatric rheumatologist is essential to monitor the course of the therapy. The most critical side effects affect the blood and liver values, which must be checked every 1-2 weeks after starting treatment and every 1-3 months as treatment progresses. The increased risk of infection must also be taken into account. Folic acid should be substituted ( $5 \mathrm{mg}$ per week) during the time that MTX is administered, as well as the 3 months following.

As a monoclonal antibody, adalimumab is a biologic that targets the hyper-inflammatory cytokine TNF- $\alpha$ (short for tumour necrosis factor $\alpha$ ) and neutralises it. This majorly inhibits inflammation. Its effect on JIA-associated uveitis showed outstanding success in an investigator-initiated trial (IIT) [16]. In this trial, adalimumab was administered in combination with MTX, and this is how it should be primarily used. This combination therapy is useful because it strengthens the effect and the MTX inhibits the development of antibodies that fight the biologic drug. In case of intolerance to MTX, other c-DMARDs such as azathioprine can also be used. If the therapeutic effect of adalimumab decreases, it might be due to such anti-drug-antibodies (ADAs), the presence of which in the blood can be established by laboratory tests. If they are found, treatment must be stopped. However, as MTX often can't be tolerated, adalimumab can also be administered as a monotherapy. Adalimumab is an on-label treatment for anterior uveitis in children. The dose is $20 \mathrm{mg}$ every 14 days for children with less than $30 \mathrm{~kg}$ bodyweight and $40 \mathrm{mg}$ every 14 days (adult dose) for children with over $30 \mathrm{~kg}$ bodyweight.

As an additional biologic drug, the blockade of the interleukin6 receptor by the antibody tocilizumab has proven effective in childhood uveitis [17-20]. Additionally, it is also helpful with treatment-resistant cystoid macular oedema [21]. It can be administered wither intravenously or subcutaneously; however, it is not approved for either indication. 


\section{Antientzündliche Therapie der Uveitis bei juveniler idiopathischer Arthritis}

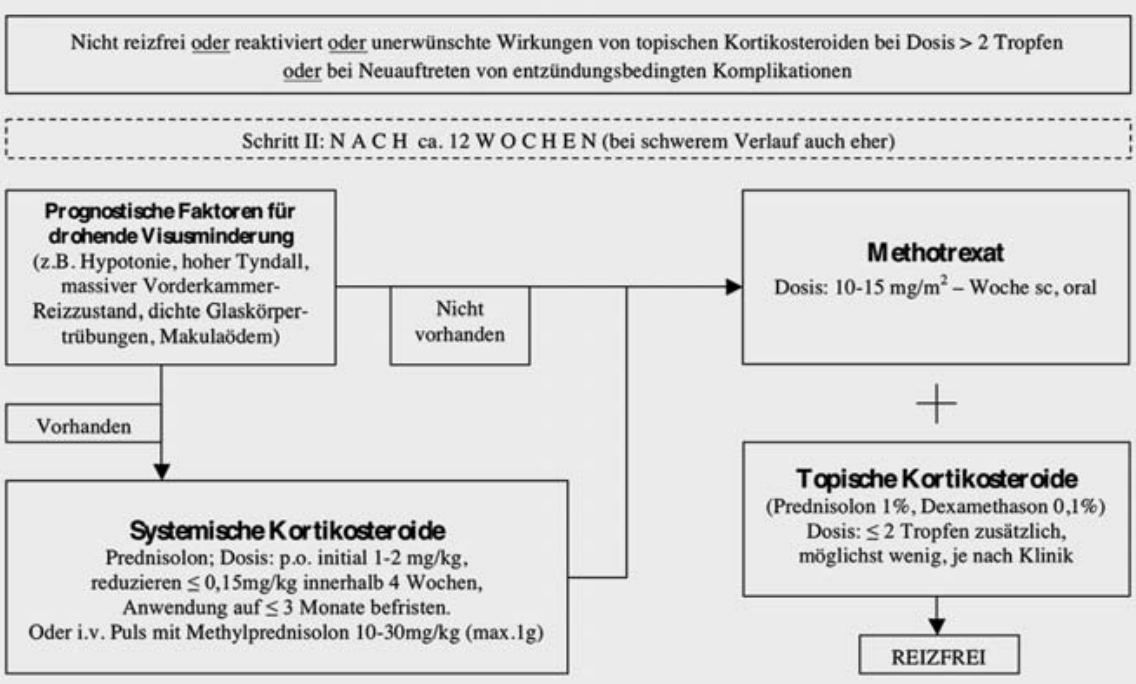

- Fig. 2 Step II of anti-inflammatory treatment of uveitis associated with juvenile idiopathic arthritis. This step describes the first steps of systemic treatment. There are generally 2 scenarios for this: 1.) Step 1 (see Fig.[F1]) was unsuccessful in reducing the topical steroid administration frequency to 2 drops or less per day within 12 weeks, or a reduction in frequency led to a relapse or the occurrence of a new complication (usually new posterior synechiae). In this scenario, it is indicated to start with the DMARD methotrexate (MTX), which may be accompanied by topical steroids in small doses (2 drops or less per day) if necessary. 2.) At the time of diagnosis, there are already unfavourable factors for visual development such as hypotension, severe anterior chamber inflammation (with lots of cells and Tyndall effect), dense vitreous opacities or (cystoid) macular oedema. In this case, systemic steroids in high oral doses (up to $2 \mathrm{mg}$ prednisolone per day) and, under unfavourable circumstances, also as intravenous pulse therapy are required alongside treatment with cortisone-containing drops. Due to the unfavourable visual prognosis in such a scenario, treatment with a DMARD (MTX) must also be commenced early in order to reduce steroid use. Source: Heiligenhaus A, Minden K, Tappeiner C et al. Leitlinie 045-012, S2k, Diagnostik und antientzündliche Therapie der Uveitis bei juveniler idiopathischer Arthritis. 2018. Im Internet (Stand: 06.09.2020): https://www.awmf.org/leitlinien/detail/II/045-012.html [rerif]

Rituximab is also a monoclonal antibody, but one that targets the cell surface molecule CD 20 on B cells. Although B cells are not directly involved in the inflammation, they appear to be important in antigen presentation and regulation. In a cohort of 10 children with uveitis, 7 improved considerably with rituximab; despite this, rituximab has not been able to achieve great importance in therapy since $[4,22]$.

With effective, early treatment, uveitis activity can be considerably reduced and the frequency of ocular complications and operations simultaneously lowered [23].

\section{Treatment of non-infectious intermediate and posterior uveitis}

Eye drops are hardly effective against intermediate and posterior uveitis because they do not diffuse far enough into the eye. Instead, steroids can be administered parabulbarly or intravitreally as a long-acting dexamethasone implant, which is approved in Germany for use in adults with non-infectious uveitis of the posterior eye segment [24]. Treatment is carried out systemically with steroids or DMARDs such as MTX (see above), ciclosporin, azathioprine or mycophenolates [25]. Whether TNF- $\alpha$ inhibitors work just as well on children with uveitis of the posterior eye segment as on adults, or whether they could trigger symptoms of multiple sclerosis in cases of intermediate uveitis, has not been well inves- tigated [26,27]. Generally, however, the principles of adult treatment can be applied to children provided the differences in bodyweight are accounted for $[26,28]$.

\section{Intraocular and parabulbar steroids}

The intraocular or parabulbar administration of steroids is highly effective for treating inflammation and cystoid macular oedema. Steroids such as parabulbar triamcinolone or the long-acting intravitreal dexamethasone implant are highly effective in cases of inflammation and macular oedema [29-31]. These treatment options are limited by the stress caused by anaesthesia and typical side effects such as cataract and glaucoma. One-off administration on the other hand, for instance in the scope of an intraocular cataract or glaucoma operation, is extremely helpful [32]. Recently, a lesser but considerably longer-acting fluocinolone acetonide implant has been approved for the treatment of uveitis in adult patients, though not for uveitis in childhood. It might be considered as an off-label medication for remission maintenance in specific cases. 
Antientzündliche Therapie der Uveitis bei juveniler idiopathischer Arthritis

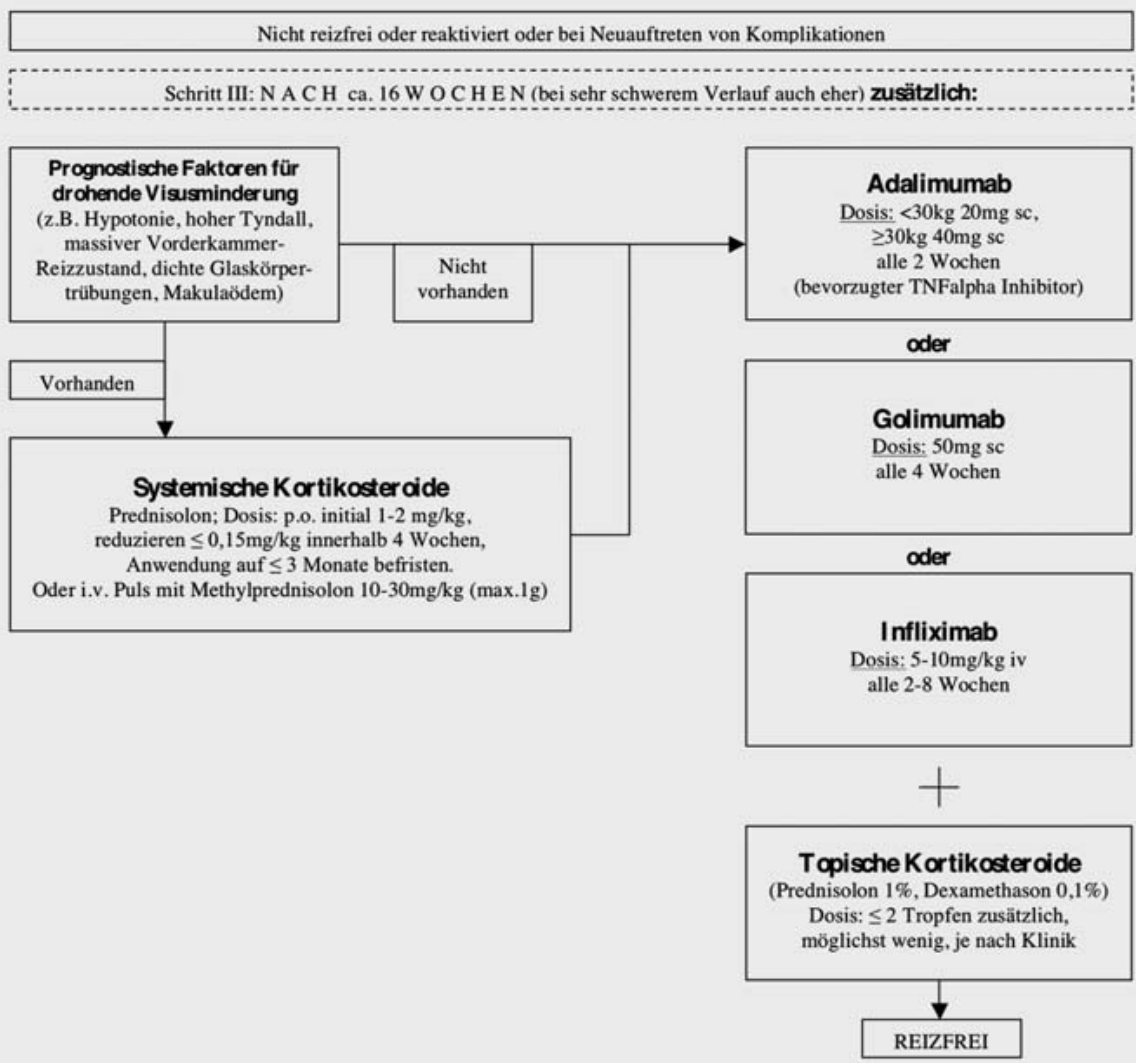

- Fig. 3 Step III of anti-inflammatory treatment of uveitis associated with juvenile idiopathic arthritis. Step III describes the route to treatment with biologics and is usually only implemented after the previous steps. The biologics of choice are TNF- $\alpha$ inhibitors with the active ingredient adalimumab, which is approved for juvenile arthritis and uveitis; under some circumstances, other TNF- $\alpha$ inhibitors that are not approved for JIA or childhood uveitis but are listed as treatment options in the updated AWMF guideline 045-012 can also be used. Source: Heiligenhaus A, Minden K, Tappeiner C et al. Leitlinie 045-012, S2k, Diagnostik und antientzündliche Therapie der Uveitis bei juveniler idiopathischer Arthritis. 2018. Im Internet (Stand: 06.09.2020): https://www.awmf.org/leitlinien/detail/II/045-012.html [rerif]

\section{Uveitis Complications}

The actual acute and chronic vision problems brought by uveitis in childhood generally do not result directly from the inflammation, but rather from the complications in entails ( $\triangleright$ Table 4$)[13,33]$.

\section{Band keratopathy}

Band keratopathy in the area of the palpebral fissure is typically the result of chronic inflammation and the associated $\mathrm{pH}$ changes in the tear film in $10-40 \%$ of the juvenile uveitis types [13,34] and appears to be more common in children up to the age of 8 years [35]. Additionally, they are also aggravated by phosphate-containing eye drops, which must be avoided as a result. The standard treatment is removal using chelating agents (e.g. EDTA) or phototherapeutic keratectomy $[34,36]$.

\section{Posterior synechia}

Posterior synechiae occur in up to $50 \%$ of the eyes, whereby they are rarer in children with later-onset uveitis [35]. Posterior syne- chiae contribute to cataract development [37], for which reason a drug-based removal of the adhesions should always be sought. This is particularly effective while the adhesions are fresh and held in place by fibrin. If scarring occurs and the fibrin is replaced by fibroblast-containing scar tissue, the drug-based synechiolysis is usually no linger possible. Posterior synechiae are prognostically unfavourable in the case of chromic inflammation and ocular hypotension [34, 38].

\section{Secondary cataract}

Secondary cataract represents one of the big challenges because it is a consequence of inflammation of the posterior synechiae or steroid therapy [39]. As such it is necessary to switch to treatment with systemic immunosuppressants in good time if chronification of the uveitis is conceivable ( $>3$ months). The goal must be the reduction of local steroids to max. 2 drops per day, in accordance with guidelines [4]. In terms of visual development, the cataract surgery without implantation of an intraocular lens has clear advantages over a primary lens implantation procedure [40] and 
- Table 4 Complications of uveitis.

\begin{tabular}{|c|c|c|}
\hline Complication & Primary causes & Note \\
\hline Band keratopathy & Anterior uveitis & $\begin{array}{l}\text { Aggravation through phosphate-containing } \\
\text { eye drops }\end{array}$ \\
\hline Corneal stromal opacities & Accompanying keratitis, mainly with viral iritis & \\
\hline Endothelial deposits & Granulomatous iritis & \\
\hline Posterior synechiae & Anterior uveitis, active inflammation. & Seek early drug-based removal, mydriatics \\
\hline Cataract & $\begin{array}{l}\text { Inflammation, mainly anterior uveitis, } \\
\text { local steroid therapy }\end{array}$ & $\begin{array}{l}\text { After 4-6 weeks, reduce steroid-containing eye } \\
\text { drops to low-potency steroids and administer max. } \\
2 \text { times per day }\end{array}$ \\
\hline Glaucoma & $\begin{array}{l}\text { Inflammation, mainly anterior uveitis, } \\
\text { local steroid therapy }\end{array}$ & $\begin{array}{l}\text { Caution when using alpha- } 2 \text { agonists and } \\
\text { prostaglandin derivatives. }\end{array}$ \\
\hline Ocular hypotension & $\begin{array}{l}\text { High inflammation activity in the anterior chamber, } \\
\text { other uveitis-associated ocular complications, } \\
\text { previous ocular operations }\end{array}$ & $\begin{array}{l}\text { Associated with poor visual prognosis, treatment } \\
\text { very extensive and often unsuccessful. Prevention } \\
\text { through good inflammation control is decisive. }\end{array}$ \\
\hline Cystoid macular oedema & $\begin{array}{l}\text { Intraocular inflammation activity (IL-6, VEGF, } \\
\text { prostaglandin), pseudophakia, intermediate or } \\
\text { posterior uveitis }\end{array}$ & $\begin{array}{l}\text { Cystoid macular oedema must be treated like } \\
\text { posterior uveitis, even in the case of anterior uveitis. }\end{array}$ \\
\hline
\end{tabular}

should also only be considered when good control of inflammation activity has been achieved [41]. Visual prognosis can be improved if the primary lens implantation precedes the insertion of a dexamethasone implant [42]. Long-term experience relating to this procedure is currently lacking; above all it is unclear how often dexamethasone implants have to be reinjected and what implications this has on a potential case of glaucoma.

\section{Glaucoma}

Similarly to a cataract, glaucoma is the result of inflammation and steroid therapy in approx. $1 / 4$ of patients $[43,44]$. Alongside the symptomatic reduction of pressure with anti-glaucoma agents, steroid-free treatment is likewise recommended for glaucoma. Alpha- 2 agonists and prostaglandin derivatives can promote the inflammation, and the latter can also cause cystoid macular oedema [45-47]. As such, these substance classes should only be used as reserve medications for glaucoma therapy and discontinued if the corresponding side effects occur. Trabeculectomy and the implantation of an Ahmed valve are helpful as operative measures for improving aqueous humour flow if drug-based treatment is no longer sufficient. Both are similarly effective with regard to pressure reduction, but intraocular inflammation is considerably lower following the trabeculectomy [48]. Surgical interventions with the aim of destroying the ciliary body in order to reduce aqueous humour production can frequently lead to the development of phthisis bulbi later down the line.

\section{Ocular hypotension}

Occurring in 3-9\% of children with JIA-associated uveitis, ocular hypotension is not a very common complication, but can represent a serious risk for vision [49]. The most important risk factors are other uveitis-associated complications and previous ocular operations. Tractions on the ciliary body, atrophy of the ciliary body and its epithelium and a prostaglandin-dependent increase uveoscleral outflow are discussed as causes [50-52]. The vision- limiting consequences of hypotension are oedema of the papilla, choroid, retina and particularly the macula. Additionally, the leakage of protein from retinal and uveal vessels (Tyndall in the anterior chamber) is increased. Chronic ocular hypotension increases the risk of developing phthisis bulbi and serious visual impairment/blindness [38]. System treatment with DMARDs reduces the risk of developing hypotension [38]. If a case of hypotension already exists, the administration of topical and systemic steroids, the switch to conventional or biological DMARDs and, if necessary, the intensification of a systemic DMARD only have limited effectiveness.

\section{Cystoid macular oedema}

One of the main causes of visual reduction in childhood uveitis is cystoid macular oedema (CMO) $[21,33,53]$. The most important risk factors are high intraocular inflammation activity with an increased IL-6 VEGF and prostaglandins, and pseudophakia [40]. With regard to the anatomical localisation, intermediate and posterior uveitis are more commonly associated with CMO than anterior types. CMO should be quickly and intensively treated with steroids (topical, parbulbar, systemic), whereby the side effects of the treatment often limit its duration and intensity. As such it is wise to quickly commence or intensify an immunosuppressive treatment with conventional DMARDs and, if required, biologics. From the TNF inhibitor group, infliximab is relatively effective, but the interleukin- 6 antagonist tocilizumab has also been used with success $[21,54]$.

\section{Conflict of Interest}

Fa. Allergan: consultancy agreement, Fa. Alimera: consultancy agreement. 


\section{References}

[1] Paroli MP, Spinucci G, Liverani M et al. Uveitis in childhood: an Italian clinical and epidemiological study. Ocul Immunol Inflamm 2009; 17: 238242

[2] Jabs DA, Nussenblatt RB, Rosenbaum JT. Standardization of uveitis nomenclature for reporting clinical data. Results of the First International Workshop. Am J Ophthalmol 2005; 140: 509-516

[3] Heiligenhaus A, Minden K, Tappeiner C et al. Leitlinie 045-012, S2k, Diagnostik und antientzündliche Therapie der Uveitis bei juveniler idiopathischer Arthritis. 2018. Accessed September 6, 2020 at: https:// www.awmf.org/leitlinien/detail/I/045-012.html

[4] Heiligenhaus A, Minden K, Tappeiner $C$ et al. Update of the evidence based, interdisciplinary guideline for anti-inflammatory treatment of uveitis associated with juvenile idiopathic arthritis. Semin Arthritis Rheum 2019; 49: 43-55

[5] LaMattina KC, Koreishi AF. What is new in paediatric uveitis? Curr Opin Ophthalmol 2018; 29: 412-418

[6] Petty RE, Southwood TR, Manners P et al. International League of Associations for Rheumatology classification of juvenile idiopathic arthritis: second revision, Edmonton, 2001. J Rheumatol 2004; 31: 390-392

[7] Khochtali S, Abroug N, Megzari K et al. Swept-source optical coherence tomography angiography findings in uveitic cystoid macular edema. Ocul Immunol Inflamm 2019; 27: 1211-1223

[8] Sancho L, Kramer M, Koriat A et al. Complications in intermediate uveitis: prevalence, time of onset, and effects on vision in short-term and long-term follow-up. Ocul Immunol Inflamm 2019; 27: 447-455

[9] Engelhard SB, Bajwa A, Reddy AK. Causes of uveitis in children without juvenile idiopathic arthritis. Clin Ophthalmol 2015; 9: 1121-1128

[10] Poddighe D, Mukusheva Z, Dauyey K et al. Adalimumab in the treatment of pediatric Behcet's disease: case-based review. Rheumatol Int 2019; 39: $1107-1112$

[11] Diwo E, Gueudry J, Saadoun D et al. Long-term efficacy of interferon in severe uveitis associated with Behçet disease. Ocul Immunol Inflamm 2017; 25: 76-84

[12] Guillaume-Czitrom S, Berger C, Pajot C et al. Efficacy and safety of interferon-alpha in the treatment of corticodependent uveitis of paediatric Behcet's disease. Rheumatology (Oxford) 2007; 46: 1570-1573

[13] Morelle G, Gueudry J, Uettwiller F et al. Chronic and recurrent non-infectious paediatric-onset uveitis: a French cohort. RMD Open 2019; 5: e000933

[14] Smith JA, Mackensen F, Sen HN et al. Epidemiology and course of disease in childhood uveitis. Ophthalmology 2009; 116: 1544-1551, 1551.e1

[15] Gordon KB, Rugo HS, Duncan JL et al. Ocular manifestations of leukemia. Leukemic infiltration versus infectious process. Ophthalmology 2001; 108: $2293-2300$

[16] Ramanan AV, Dick AD, Benton D et al. A randomised controlled trial of the clinical effectiveness, safety and cost-effectiveness of adalimumab in combination with methotrexate for the treatment of juvenile idiopathic arthritis associated uveitis (SYCAMORE Trial). Trials 2014; 15: 14

[17] Calvo-Río V, Santos-Gómez M, Calvo I et al. Anti-interleukin-6 receptor tocilizumab for severe juvenile idiopathic arthritis-associated uveitis refractory to anti-tumor necrosis factor therapy: A multicenter study of twenty-five patients. Arthritis Rheumatol 2017; 69: 668-675

[18] Tappeiner C, Mesquida M, Adan A et al. Evidence for tocilizumab as a treatment option in refractory uveitis associated with juvenile idiopathic arthritis. J Rheumatol 2016; 43: 2183-2188

[19] Horneff G, Klein A, Klotsche J et al. Comparison of treatment response, remission rate and drug adherence in polyarticular juvenile idiopathic arthritis patients treated with etanercept, adalimumab or tocilizumab. Arthritis Res Ther 2016; 18: 272
[20] Adan A, Mesquida M, Llorenc $V$ et al. Tocilizumab treatment for refractory uveitis-related cystoid macular edema. Graefes Arch Clin Exp Ophthalmol 2013; 251: 2627-2632

[21] Vegas-Revenga N, Calvo-Rio V, Mesquida M et al. Anti-IL6-receptor tocilizumab in refractory and noninfectious uveitic cystoid macular edema: Multicenter study of 25 patients. Am J Ophthalmol 2019; 200: 85-94

[22] Heiligenhaus A, Miserocchi E, Heinz C et al. Treatment of severe uveitis associated with juvenile idiopathic arthritis with anti-CD20 monoclonal antibody (rituximab). Rheumatology 2011; 50: 1390-1394

[23] Tappeiner C, Klotsche J, Schenck $S$ et al. Temporal change in prevalence and complications of uveitis associated with juvenile idiopathic arthritis: data from a cross-sectional analysis of a prospective nationwide study. Clin Exp Rheumatol 2015; 33: 936-944

[24] Lowder C, Belfort R jr., Lightman S et al. Dexamethasone intravitreal implant for noninfectious intermediate or posterior uveitis. Arch Ophthalmol 2011; 129: 545-553

[25] Winterhalter S, Niehues T. TNFalpha-blocking agents or conventional immunosuppressive drugs in the therapy of children with uveitis? An evidence based approach. Klin Padiatr 2008; 220: 342-347

[26] Jabs DA. Immunosuppression for the uveitides. Ophthalmology 2018; 125: 193-202

[27] Li SY, Birnbaum AD, Goldstein DA. Optic neuritis associated with adalimumab in the treatment of uveitis. Ocul Immunol Inflamm 2010; 18: 475-481

[28] Shahab MA, Mir TA, Zafar S. Optimising drug therapy for non-infectious uveitis. Int Ophthalmol 2019; 39: 1633-1650

[29] Bratton ML, He YG, Weakley DR. Dexamethasone intravitreal implant (Ozurdex) for the treatment of pediatric uveitis. J AAPOS 2014; 18: $110-113$

[30] Totan Y, Güler E, Guragaç FB et al. Cystoid macular edema associated with juvenile idiopathic arthritis resolved by a dexamethasone intravitreal implant. J Pediatr Ophthalmol Strabismus 2014; 51: e25-e28

[31] Garweg JG. Macular edema in childhood uveitis. Klin Monbl Augenheilkd 2018; 235: 373-376

[32] Grajewski RS, Zurek-Imhoff B, Roesel M et al. Favourable outcome after cataract surgery with $\mathrm{IOL}$ implantation in uveitis associated with juvenile idiopathic arthritis. Acta Ophthalmol 2012; 90: 657-662

[33] Angeles-Han ST, McCracken C, Yeh S et al. Characteristics of a cohort of children with juvenile idiopathic arthritis and JIA-associated uveitis. Pediatr Rheumatol Online J 2015; 13: 19

[34] Oray M, Khachatryan N, Ebrahimiadib N et al. Ocular morbidities of juvenile idiopathic arthritis-associated uveitis in adulthood: results from a tertiary center study. Graefes Arch Clin Exp Ophthalmol 2016; 254: 1841-1849

[35] Al-Haddad C, BouGhannam A, Abdul Fattah M et al. Patterns of uveitis in children according to age: comparison of visual outcomes and complications in a tertiary center. BMC Ophthalmol 2019; 19: 137

[36] Rathi VM, Vyas SP, Vaddavalli PK et al. Phototherapeutic keratectomy in pediatric patients in India. Cornea 2010; 29: 1109-1112

[37] Blum-Hareuveni T, Seguin-Greenstein S, Kramer M et al. Risk factors for the development of cataract in children with uveitis. Am J Ophthalmol 2017; 177: 139-143

[38] Moradi A, Stroh IG, Reddy AK et al. Risk of hypotony in juvenile idiopathic arthritis-associated uveitis. Am J Ophthalmol 2016; 169: 113-124

[39] Thorne JE, Woreta FA, Dunn JP et al. Risk of cataract development among children with juvenile idiopathic arthritis-related uveitis treated with topical corticosteroids. Ophthalmology 2010; 117: 1436-1441

[40] Yangzes S, Seth NG, Singh R et al. Long-term outcomes of cataract surgery in children with uveitis. Indian J Ophthalmol 2019; 67: 490-495

[41] Kulik U, Wiklund A, Kugelberg $M$ et al. Long-term results after primary intraocular lens implantation in children with juvenile idiopathic arthritis-associated uveitis. Eur J Ophthalmol 2019; 29: 494-498 
[42] Jinagal J, Gupta G, Agarwal A et al. Safety and efficacy of dexamethasone implant along with phacoemulsification and intraocular lens implantation in children with juvenile idiopathic arthritis associated uveitis. Indian J Ophthalmol 2019; 67: 69-74

[43] Kothari S, Foster CS, Pistilli M et al. The risk of intraocular pressure elevation in pediatric noninfectious uveitis. Ophthalmology 2015; 122: 19872001

[44] Gautam Seth N, Yangzes S, Thattaruthody F et al. Glaucoma secondary to uveitis in children in a tertiary care referral center. Ocul Immunol Inflamm 2019; 27: 456-464

[45] Hayasaka Y, Hayasaka S, Zhang XY et al. Effects of topical antiglaucoma eye drops on prostaglandin $\mathrm{E}(2)$-induced aqueous flare elevation in pigmented rabbits. Invest Ophthalmol Vis Sci 2002; 43: 1142-1145

[46] Fechtner RD, Khouri AS, Zimmerman T] et al. Anterior uveitis associated with latanoprost. Am J Ophthalmol 1998; 126: 37-41. doi:10.1016/ s0002-9394(98)00071-3

[47] Halpern DL, Pasquale LR. Cystoid macular edema in aphakia and pseudophakia after use of prostaglandin analogs. Semin Ophthalmol 2002; 17: 181-186

[48] Wiese C, Heiligenhaus AM, Heinz CMF. Changes in inflammatory activity after glaucoma filtration surgery in children with chronic anterior uveitis.
Ocul Immunol Inflamm 2016; 24: 397-401. doi:10.3109/09273948. 2015.1088041

[49] Böhm MR, Tappeiner C, Breitbach MA et al. Ocular hypotony in patients with juvenile idiopathic arthritis-associated uveitis. Am J Ophthalmol 2017; 173: 45-55

[50] Sen HN, Drye LT, Goldstein DA et al. Hypotony in patients with uveitis: The Multicenter Uveitis Steroid Treatment (MUST) trial. Ocul Immunol Inflamm 2012; 20: 104-112

[51] Loh AR, Acharya NR. Incidence rates and risk factors for ocular complications and vision loss in HLA-B27-associated uveitis. Am J Ophthalmol 2010; 150: 534-542.e2

[52] Tran VT, Mermoud A, Herbort CP. Appraisal and management of ocular hypotony and glaucoma associated with uveitis. Int Ophthalmol Clin 2000; 40: 175-203

[53] Eiger-Moscovich M, Tomkins-Netzer O, Amer R et al. Visual and clinical outcome of macular edema complicating pediatric noninfectious uveitis. Am J Ophthalmol 2019; 202: 72-78

[54] Miraldi Utz V, Bulas S, Lopper S et al. Effectiveness of long-term infliximab use and impact of treatment adherence on disease control in refractory, non-infectious pediatric uveitis. Pediatr Rheumatol Online J 2019; 17: 79 